JURNAL TERKNOSAINS

VOLUME 2

No. 2, 22 Juni 2013

Halaman 71-158

\title{
APLIKASI KOAGULAN ALAMI DARI TEPUNG JAGUNG DALAM PENGOLAHAN AIR BERSIH
}

\author{
Eka Prihatinningtyas \\ Pusat Penelitian Limnologi LIPI \\ Email: ekatyas@yahoo.com \\ Agus Jatnika Effendi \\ Jurusan Teknik Lingkungan \\ Institut Teknologi Bandung
}

\begin{abstract}
Maize can be used as natural coagulant in water treatment process. The aim of this research was find the optimum condition on water treatment using natural coagulant from maize. Maize extract made by dissolving 5 grams of maize into $100 \mathrm{ml} \mathrm{NaCl}$. The solution separated by centrifugation. The supernatant named extract of maize. Extract of maize loaded onto column packed with Amberlite and produced ionic maize. The active components are carboxyl, hydroxyl and amides groups. Ionic maize yield better turbidity removal than extract of maize. Coagulation withh high initial turbidity gave high efficiency of turbidity removal than low turbidity. Coagulation process runs efficiently at $\mathrm{pH} 5$ because at that point the isoelectric point was obtained. The flowrate less than $0.03 \mathrm{~m} / \mathrm{min}$, the alum will provide the efficiency of suspended solids removal greater than extract of maize. While the over flowrate higher than $0.03 \mathrm{~m} / \mathrm{min}$, settling velocity of kaolin using alum and extract of maize are the same.
\end{abstract}

Keywords: Coagulation, Natural Coagulant, Extract of Maize, Ionic Maize.

\begin{abstract}
ABSTRAK
Tepung jagung dapat dimanfaatkan sebagai koagulan dalam pengolahan air bersih. Ekstrak jagung dibuat dengan melarutkan 5 gram tepung jagung dalam $100 \mathrm{ml} \mathrm{NaCl}$. Selanjutnya campuran tersebut dipisahkan dengan sentrifugasi. Supernatan yang diperoleh dinamakan ekstrak jagung. Ekstrak jagung yang dilewatkan dalam resin Amberlite akan menjadi jagung ionik. Hasil percobaan menunjukkan bahwa ekstrak jagung dan jagung ionik bersifat polielektrolit dan mengandung gugus karboksil, hidroksil dan amida yang berperan sebagai komponen aktif koagulasi. Jagung ionik memberikan efisiensi koagulasi yang lebih baik dibandingkan dengan ekstrak jagung. Proses koagulasi yang terjadi pada kekeruhan awal yang tinggi memberikan efisiensi penurunan kekeruhan yang lebih baik dibandingkan dengan kekeruhan rendah. Proses koagulasi berjalan dengan efisien pada pH 5 karena pada titik tersebut diperoleh titik isoelektrik. Pada over flowrate kurang dari 0,03 m/menit, alum akan memberikan efisiensi penyisihan padatan tersuspensi yang lebih besar daripada ekstrak jagung, sedangkan pada over flowrate lebih dari $0,03 \mathrm{~m} /$ menit kecepatan pengendapan kaolin dengan alum sama dengan ekstrak jagung.
\end{abstract}

Kata Kunci: Koagulasi, Koagulan Alami, Ekstrak Jagung, Jagung Ionik. 


\section{PENGANTAR}

Air bersih merupakan kebutuhan manusia yang sangat penting. Belum semua penduduk Indonesia mendapatkan akses air bersih. Air baku yang akan diolah menjadi air bersih juga mengalami penurunan kualitas. Oleh karena itu, diperlukan suatu pembaharuan atau inovasi dalam hal teknologi, proses maupun bahan aditif yang digunakan dalam pengolahan air bersih.

Salah satu bahan aditif yang ditambahkan dalam pengolahan air bersih adalah koagulan. Koagulan adalah bahan kimia yang ditambahkan ke dalam air untuk mengendapkan partikel-partikel koloid yang sulit terhilangkan di dalam air. Penggunaan koagulan pada proses koagulasi untuk destabilisasi muatan dengan menekan/ menghilangkan lapisan diffused layer sehingga yang tersisa adalah gaya tarik menarik antarpartikel (Van der Waals).

Koagulan memegang peranan cukup penting dalam pengolahan air bersih yaitu dalam hal menurunkan kekeruhan, total dissoloved solid (TDS) dan total suspended solid (TSS). Menurut Kawamura (1991), koagulan yang digunakan dapat dibedakan menjadi polimer anorganik dan polimer alami. Koagulan yang umum digunakan adalah koagulan kimia seperti alum sulfat, poly aluminium chloride, ferro sulfat $\left(\mathrm{FeSO}_{4}\right)$, dan ferri khlorida $\left(\mathrm{FeCl}_{3}\right)$. Menurut Ozacar bahwa koagulan kimia dapat memacu timbulnya penyakit Alzheimer (Ozacar, 2003). Oleh karena itu, saat ini sedang dikembangkan pemanfaatan bahan alami sebagai koagulan karena memiliki beberapa keuntungan antara lain bersifat biodegradable, lebih aman terhadap kesehatan manusia dan lebih ekonomis. Koagulan alami dapat dijumpai dengan mudah karena dapat diambil atau diekstrak dari bahan lokal berupa tumbuhan dan hewan.

Tepung dari berbagai jenis tumbuhan dapat juga digunakan sebagai koagulan alami. Salah satunya adalah tepung jagung yang terbuat dari jagung. Produksi dan konsumsi jagung mengalami kenaikan setiap tahun. Produksi jagung di Indonesia sudah mengalami surplus sejak tahun 2008. Diprediksikan jumlah produksi jagung akan semakin tinggi dibandingkan dengan jumlah konsumsinya. Akan tetapi, pemanfaatan jagung saat ini masih didominasi oleh konsumsi langsung (Zubachtirodin, 2010).

Fatehah (2007) telah melakukan penelitian dengan menggunakan tepung untuk mengolah limbah semi konduktor. Pada penelitian tersebut, Fatehah menggunakan tepung jagung, tepung beras, dan tepung sagu. Pemanfaatan tepung jagung untuk mengolah limbah cair tahu dapat dikaji karena jumlahnya yang melimpah dan harganya murah.

Berbagai studi tentang penggunaan koagulan alami telah banyak dilakukan. Moringa oleifera adalah bahan yang banyak dikaji. Penelitian dengan menggunakan bahan ini telah banyak dilakukan antara lain oleh Srawaili (2008) yang menggunakan limbah artifisial. Katayon dkk., (2007) menggunakan ekstrak Moringa oleifera untuk mengolah efluen dari secondary oxidation pond dan Bhuptawat dkk., (2007) yang mengolah limbah cair kota. Penelitian serupa dengan menggunakan biji anggur dilakukan oleh Jeon dkk., (2009) untuk menghilangkan zat warna pada limbah tekstil. Antov dkk., (2010) menggunakan ekstrak Phaseolus vulgaris dan Phaseolus vulgaris ionik untuk mengolah limbah kaolin. Heredia dkk., (2011) memanfaatkan ekstrak tannin untuk mengolah limbah cair kota dan air sungai. Penelitian lain juga dilakukan dengan menggunakan ekstrak Opuntia sp (Moreno, 2009). Patel dkk., (2011) menggunakan tiga macam koagulan yaitu ekstrak Moringa oleifera, chitosan, dan ekstrak jagung untuk menurunkan kadar zat warna Congo Red dalam limbah tekstil.

Penelitian ini dilakukan di Laboratorium Kualitas Air Program Studi Teknik Lingkungan ITB sejak bulan Januari sampai dengan Juni 2012. Air baku yang diolah menjadi air bersih 
tersusun atas banyak komponen (multipollutant) yang nilainya cukup fluktuatif setiap harinya.Halini tentusaja sangatmempengaruhi proses penentuan aktivitas koagulasi. Pada penelitian ini penentuan aktivitas koagulasi dilakukan dengan cara membandingkan besarnya kekeruhan yang tersisihkan dengan kekeruhan awal. Oleh karena itu, digunakan limbah artifisial yang kekeruhannya dibuat hampir mendekati kekeruhan air sungai sebagai air baku untuk air bersih. Bahan kimia yang umum digunakan sebagai sumber koloid adalah kaolin. Kaolin banyak digunakan dalam laboratorium untuk membuat limbah artifisial yang berhubungan dengan kekeruhan. Selain itu, harga kaolin relatif tidak mahal, mudah didapat dan mudah dalam penanganannya. Penelitian laboratorium yang menggunakan kaolin sebagai sumber koloid antara lain Sciban dkk., (2009), Srawaili (2008) dan Antov dkk.,(2010).

Limbah artifisial dibuat dengan cara melarutkan 1 gram kaolin dalam air kran kemudian diaduk selama 1 jam dengan menggunakan stirrer. Tujuan pengadukan adalah membuat larutan kaolin menjadi homogen. Tahap selanjutnya adalah mendiamkan larutan kaolin selama 24 jam untuk memastikan bahwa proses hidrasi partikel telah berlangsungdengan baik. Larutan ini selanjutnya dinamakan larutan induk. Larutan induk kemudian diencerkan dengan menggunakan air kran untuk mendapatkan kekeruhan yang diinginkan (Antov dkk., 2010). Proses pengenceran dilakukan sesaat sebelum jartest koagulasi dilaksanakan. Pada penelitian ini digunakan tiga macam variasi kekeruhan yaitu 50, 150, dan 300 NTU.

Komponen aktif dari tepung jagung yang berperan dalam proses koagulasi dapat diperoleh dengan cara ekstraksi. Ekstrak tepung jagung diperoleh dengan cara melarutkan 5 gram tepung ke dalam $100 \mathrm{ml} \mathrm{NaCl} 1 \mathrm{M}$. Larutan diaduk selama 30 menit dan selanjutnya dipisahkan dengan cara sentrifugasi. Supernatan yang diperoleh dinamakan ekstrak tepung. Ekstrak tepung digunakan pada hari yang sama dengan waktu percobaan koagulasi. Pembuatan jagung ionik dilakukan dengan cara melewatkan ekstrak tepung jagung ke dalam kolom resin penukar kation Amberlite. Kecepatan alir dalam kolom resin sebesar $1 \mathrm{ml} / \mathrm{menit}$. Jagung ionik yang dihasilkan berwarna bening (Antov dkk., 2010). Karakterisasi tepung jagung, ekstrak jagung, dan jagung ionik dilakukan dengan metode Fourier Transform Infra Red (FTIR).

Percobaan dilakukan dengan alat jartest. Sebanyak $500 \mathrm{ml}$ limbah artifisial ditambah koagulan dengan dosis tertentu, kemudian diputar pada kecepatan $200 \mathrm{rpm}$ selama 2 menit dilanjutkan dengan $60 \mathrm{rpm}$ selama 20 menit. Pengambilan sampel dilakukan setelah pengendapan selama 1 jam kemudian diukur kekeruhan akhirnya. Flok yang terbentuk selanjutnya dianalisa dengan Scanning Electron Magnetic (SEM) untuk mengetahui bentuk morfologinya. Komposisi dalam flok ditentukan dengan analisa EDX.

Selanjutnya dilakukan penentuan kecepatan pengendapandenganmenggunakan column test (tangki pengendapan). Tangki pengendapan yang digunakan mempunyai ketinggian $120 \mathrm{~cm}$ dan diameter $18 \mathrm{~cm}$. Tangki pengendapan dilengkapi dengan multiple withdrawal ports pada ketinggian 20, 40, 60, 80, dan $100 \mathrm{~cm}$. Pengambilan sampel dilakukan pada menit ke 15, 30, 45, 60, 75, 90, dan 120. Langkah selanjutnya adalah pengukuran total suspended solid secara gravimetri.

\section{PEMBAHASAN \\ Pengaruh Pemurnian Komponen Aktif terhadap Efisiensi Penurunan Kekeruhan}

Karakterisasi tepung jagung, ekstrak jagung, dan jagung ionik dilakukan untuk mengetahui komponen aktif yang berperilaku seperti koagulan. Karakterisasi koagulan dilakukan dengan metode Fourier Transform Infra Red (FTIR). Analisis ini dilakukan untuk mengetahui gugus fungsi penyusun senyawa dalam tepung jagung, 
ekstrak jagung, dan jagung ionik. Hasil analisis spektrum infra merah dengan FTIR dapat dilihat pada Gambar 1.

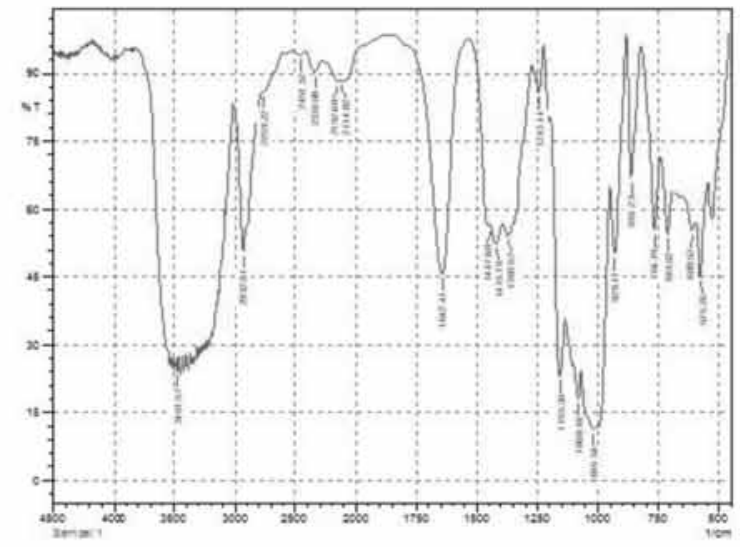

a. Tepung Jagung
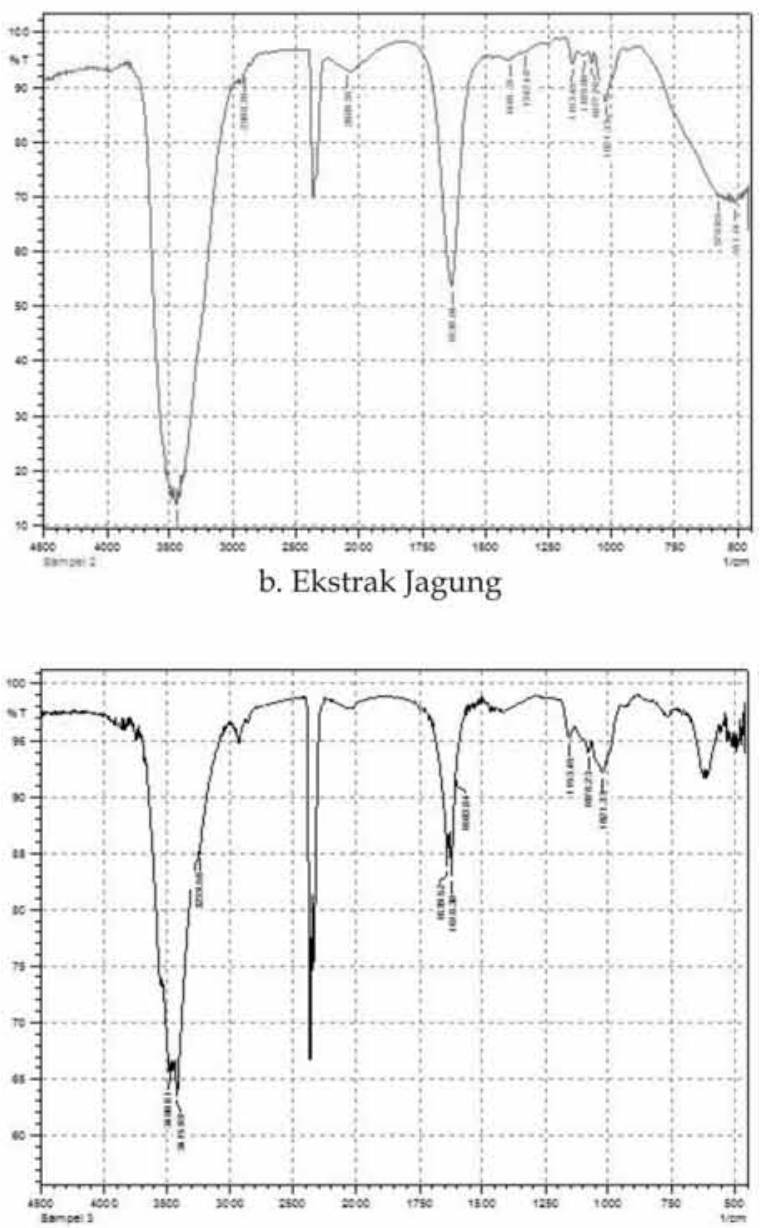

c. Jagung Ionik

Gambar 1. Hasil FTIR tepung jagung, ekstrak jagung, dan jagung ionik
Hasil spektrum infra merah menunjukkan adanya gugus -OH (hidroksil) pada panjang gelombang 3431,57 $\mathrm{cm}^{-1}$ untuk tepung jagung, $3449,75 \mathrm{~cm}^{-1}$ untuk ekstrak jagung, dan 3480,61 $\mathrm{cm}^{-1}$ untuk jagung ionik. Selain itu juga ditemukan gugus fungsi $-\mathrm{CH}$, yaitu pada panjang gelombang 2932,61 $\mathrm{cm}^{-1}$ untuk tepung jagung, 2908,70 $\mathrm{cm}^{-1}$ untuk ekstrak jagung, dan 3239,50 $\mathrm{cm}^{-1}$ untuk jagung ionik. Gugus lain yang ditemukan adalah gugus amida $\left(-\mathrm{CONH}_{2}\right)$, yaitu pada panjang gelombang $1642,41 \mathrm{~cm}^{-1}$ untuk tepung jagung, 1630,54 $\mathrm{cm}^{-1}$ untuk ekstrak jagung, dan 1618,30 $\mathrm{cm}^{-1}$ untuk jagung ionik.

Secara keseluruhan, hasil spektrum infra merah menunjukkan adanya polimer yang mengandung gugus karboksil, hidroksil, dan amida. Ketiga gugus tersebut merupakan komponen aktif dan berperan sebagai koagulan. Polimer tersebut dapat mengikat partikel koloid dan membentuk flok yang dapat mengendap.

Polimerinibersifat polielektrolit. Adanya gugus karboksil dan hidroksil menyebabkan larutan polielektrolit bermuatan negatif sedangkan gugus amida bermuatan positif. Oleh karena itu, koagulan alami dari jagung bersifat amfoter. Hasil pengukuran potensial zeta ditunjukkan pada Tabel 1 digunakan untuk mengetahui muatan koagulan.

Tabel 1. Hasil Pengukuran Potensial Zeta untuk Ekstrak Jagung dan Jagung Ionik

\begin{tabular}{l|l}
\hline Material & Potensial zeta $(\mathrm{mV})$ \\
\hline Ekstrak jagung & $-14,06$ \\
Jagung ionik & $-16,68$ \\
\hline
\end{tabular}

Nilai potensial zeta ekstrak jagung dan jagung ionik negatif, artinya komponen terbanyak dalam koagulan adalah gugus dengan muatan negatif. Hasil penelitian dengan menggunakan ekstrak jagung dan jagung ionik dapat dilihat pada Gambar 2. Pada dosis $20 \mathrm{ppm}$, efisiensi penurunan kekeruhan dengan menggunakan jagung ionik sebesar $92 \%$ dan ekstrak jagung sebesar $86 \%$. Jagung ionik memberikan efisiensi $6 \%$ lebih tinggi daripada ekstrak jagung. 
Koagulasi ini berjalan pada $\mathrm{pH} \pm 5$ dengan kekeruhan awal 300 NTU.

Menurut Antov dkk., (2003), koagulasi dengan menggunakan Phaseolus vulgaris (buncis) ionik akan memberikan aktivitas koagulasi 22 kali lebih tinggi daripada ekstrak Phaseolus vulgaris. Berbasis kekeruhan awal 35 NTU dan dosis koagulan sebesar $1 \mathrm{ml} / \mathrm{l}$, aktivitas koagulasi dengan menggunakan Phaseolus vulgaris (buncis) ionik mencapai $72,3 \%$ sedangkan dengan ekstrak Phaseolus vulgaris (buncis) hanya memperoleh 30\% saja. Aktivitas koagulasi identik dengan efisiensi penurunan kekeruhan.

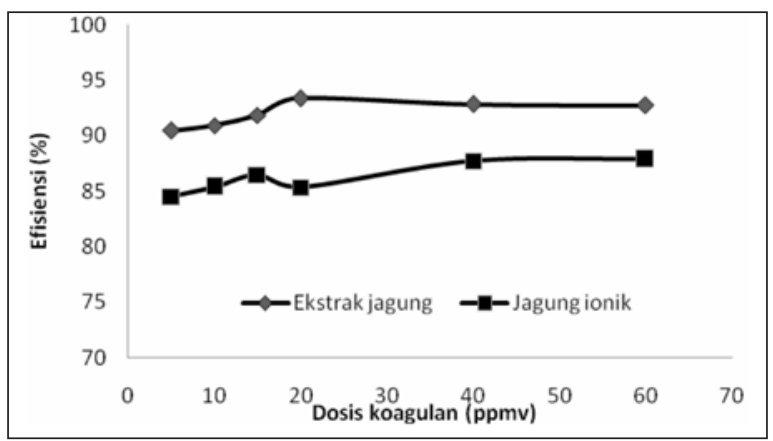

Gambar 2. Efisiensi Penurunan Kekeruhan dengan Menggunakan Ekstrak Jagung dan Jagung Ionik

\section{Pengaruh Dosis Koagulan terhadap Efisiensi Penurunan Kekeruhan}

Dosis koagulan sangat berpengaruh terhadap efisiensi penurunan kekeruhan. Hasil koagulasi pada kekeruhan awal 300 NTU pada $\mathrm{pH} \pm 5$ dengan menggunakan jagung ionik selengkapnya dapat dilihat pada Gambar 3.

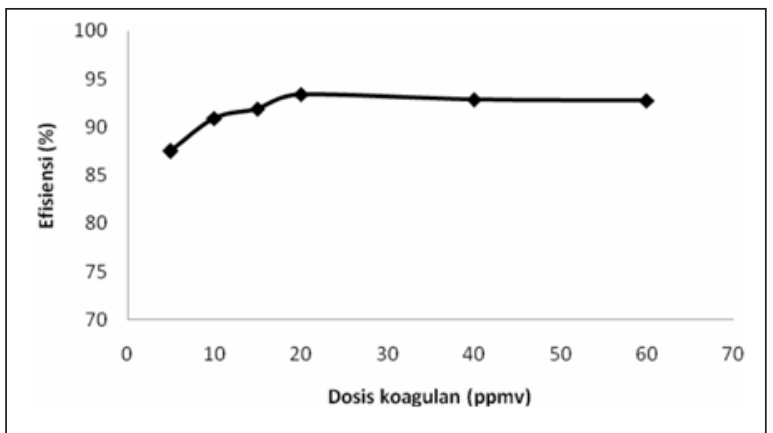

Gambar 3. Pengaruh Dosis Koagulan terhadap Efisiensi Penurunan Kekeruhan
Hasil penelitian menunjukkan bahwa semakin besar dosis koagulan yang digunakan, maka efisiensi penurunan kekeruhan juga meningkat. Penambahan dosis koagulan dari 5 sampai 20 ppm $_{\mathrm{v}}$ menunjukkan kenaikan efsiensi penurunan kekeruhan yang cukup signifikan, yaitu dari $87,53 \%$ menjadi 93,40\%. Selanjutnya penambahan dosis tidak lagi memberikan efisiensi yang cukup berarti.

Penambahan dosis koagulan yang berlebihakan memberikanefisiensipenurunan kekeruhan yang tidak berbeda jauh karena akan terjadi kegagalan pembentukan flok. Mekanisme yang terjadi adalah polimerpolimer dalam koagulan alami akan menutupi seluruh permukaan partikel koloid sehingga tidak ada tempat untuk rantai akhir menempel dan proses flokulasi tidak terjadi. Keadaan ini dapat mengakibatkan partikel koloid akan kembali stabil atau tidak dapat bergabung dengan partikel lain (Larry dan Joseph dalam Srawaili, 2008).

\section{Pengaruh pH terhadap Efisiensi Penurunan Kekeruhan}

Kondisi proses sangat mempengaruhi efektivitas koagulasi dan flokulasi. Salah satu kondisi operasi yang penting adalah derajat keasaman $(\mathrm{pH})$. Pengaruh derajat keasaman $(\mathrm{pH})$ terhadap efisiensi penurunan kekeruhan dapat dilihat pada Gambar 4.

Kaolin sebagai sumber koloid mempunyai gaya elektrostatis yang berguna untuk menjaga dispersi koloid. Permukaan partikel koloid mendapatkan gaya elektrostatik karena ionisasi dari gugus pada permukaan atau adsorpsi ion dari larutan pendispersinya (Reynolds, 1982). Pada kondisi yang sangat asam $(\mathrm{pH}= \pm 3)$, kaolin akan mengadsorpsi ion $\mathrm{H}^{+}$yang berasal dari asam yang ditambahkan ke dalam suspensi sehingga bermuatan positif. Mekanisme penurunan kekeruhan yang terjadi adalah reaksi protonasi antara ion $\mathrm{H}^{+}$pada permukaan koloid dengan gugus yang bermuatan negatif dalam koagulan 
(-COOH). Kondisi $\mathrm{pH} \pm 3$ masih berada di bawah titik isoelektrik, sehingga gugus $\mathrm{COOH}$ tidak terionisasi. Akibat perbedaan muatan antara koloid dan koagulan maka akan terbentuk ikatan ion atau hidrogen. Adanya ikatan ion atau hidrogen ini akan mengurangi atau menetralkan muatan pada permuakaan partikel koloid. Hasil yang sama juga diperoleh oleh Patel dkk., (2011) yang menggunakan chitosan, jagung, dan Moringa oleifera sebagai koagulan alami.

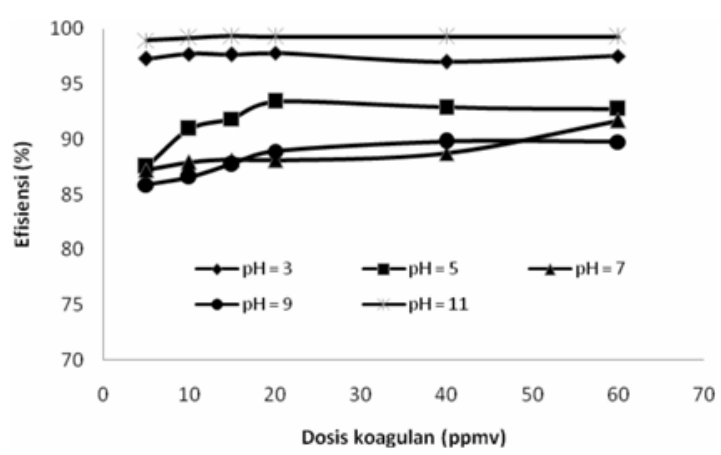

Gambar 4. Pengaruh $\mathrm{pH}$ terhadap Efisisensi Penurunan Kekeruhan

Pada $\mathrm{pH}$ di atas \pm 5 , kaolin akan bermuatan negatif. Kondisi optimum untuk koagulasi tercapai pada $\mathrm{pH} \pm 5$ karena pada kondisi tersebut dekat dengan titik isoelektrik. Menurut Belitz dan Morales-de Leon dalam Antov (2010), titik isoelektrik protein yang diekstrak dari Phaseolus vulgaris (buncis) adalah pada $\mathrm{pH}$ sekitar 4,5. Pada pH di atas titik isoelektrik, gugus karboksil $(-\mathrm{COOH})$ akan terionisasi menjadi (-COO-). Gugus -COO- berperan sebagai site adsorb yang akan mengikat reactive site dari koloid. Gugus -COO- akan membentuk sebuah "bridge" bagi koloid untuk teradsobrsi. Adsorbsi yang terjadi bersifat kimia (chemisorption) antara partikel koloid yang bemuatan dengan - $\mathrm{COO}^{-}$ - Keberadaan gugus -OH sepanjang rantai polimer akan mempengaruhi probabilitas interaksi intramolekul yang dapat mengubah linearitas rantai (Yin, 2010).

Reynolds (1982) dan Yin (2010) menjelaskan bahwa mekanisme yang terjadi pada koagulasi dengan menggunakan koagulan alami adalah netralisasi muatan dan pembentukan interparticle bridging. Reynolds (1982) menyatakan polimer organik mempunyai gugus yang mudah terionisasi seperti karboksil, amino, dan sulfunic. Gugus-gugus tersebut bereaksi dengan reactive site atau gugus yang berada pada permukaan koloid. Beberapa koloid akan terikat pada molekul polimer tunggal dan membentuk struktur ikatan. Ikatan tersebut membentuk suatu jembatan kimia. Makin banyak ikatan yang terjadi, maka makin banyak koloid yang bergabung. Penggabungan tersebut membentuk gumpalan atau flok yang dapat mengendap (Larry dan Joseph dalam Srawaili, 2008).

\section{Pengaruh Kekeruhan Awal terhadap Efisiensi Penurunan Kekeruhan}

Tingkat kekeruhan awal sangat mempengaruhi efisiensi penurunan kekeruhan. Hasil selengkapnya dapat dilihat pada Gambar 5. Kekeruhan awal mempengaruhi jumlah partikel koloid dalam limbah yang akan diolah.

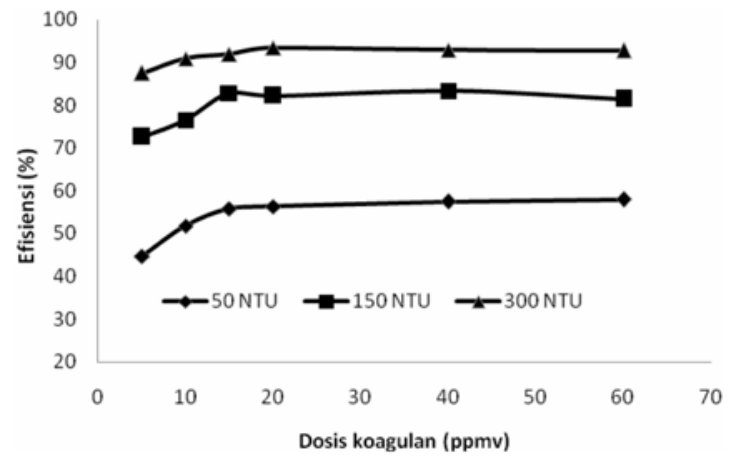

Gambar 5. Pengaruh Kekeruhan Awal terhadap Efisiensi Penurunan Kekeruhan

Penelitian dilakukan pada tiga variasi kekeruhan yang berbeda yaitu 50, 150, dan 300 NTU. Proses koagulasi yang berlangsung pada $\mathrm{pH} \pm 5$ seperti yang terlihat pada Gambar 5 menunjukkan bahwa efisiensi penurunan kekeruhan terbesar akan tercapai pada kondisi kekeruhan awal 300 NTU. Pada kekeruhan awal rendah (50 NTU), efisiensi penurunan kekeruhan yang tercapai sangat rendah sehingga dapat dikatakan bahwa 
semakin tinggi kekeruhan awal, maka efisiensi penurunan kekeruhan juga semakin besar. Pada kekeruhan yang tinggi, jumlah partikel koloid yang terkandung di dalamnya juga semakin banyak. Partikel koloid ini nantinya akan berikatan dengan partikel dalam koagulan. Semakin banyak partikel koloid, maka akan semakin banyak ikatan yang terjadi antara koloid dengan partikel koagulan. Demikian pula sebaliknya. Dengan semakin banyak ikatan yang terbentuk, maka semakin banyak flok yang dihasilkan sehingga akan diperoleh supernatan yang semakin jernih.

\section{Kecepatan Pengendapan}

Proses koagulasi flokulasi merupakan perlakuan awal untuk pengendapan tipe II, di mana selama pengendapan terjadi saling interaksi antarpartikel. Selama operasi pengendapan, maka ukuran partikel flokulen bertambah besar sehingga kecepatan pengendapannya juga meningkat. Penentuan kecepatan pengendapan dilakukan dengan mengukur total suspended solid pada setiap titik sampling pada selang waktu tertentu. Hasil pengukuran total suspended solid selanjutnya diplotkan ke dalam grafik isoremoval. Gambar 6 merupakan hasil pengukuran total suspended solid pada setiap titik sampling selama 2 jam dengan selang waktu 15 menit. Koagulan yang digunakan adalah ekstrak jagung dan alum.

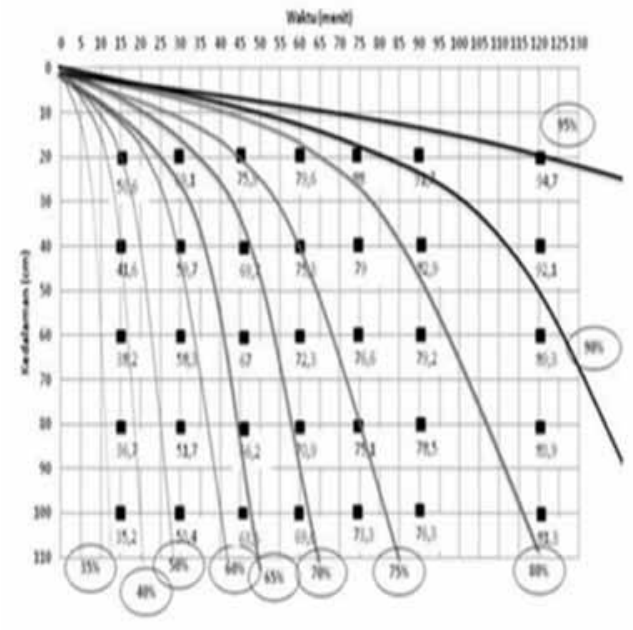

a. Ekstrak jagung

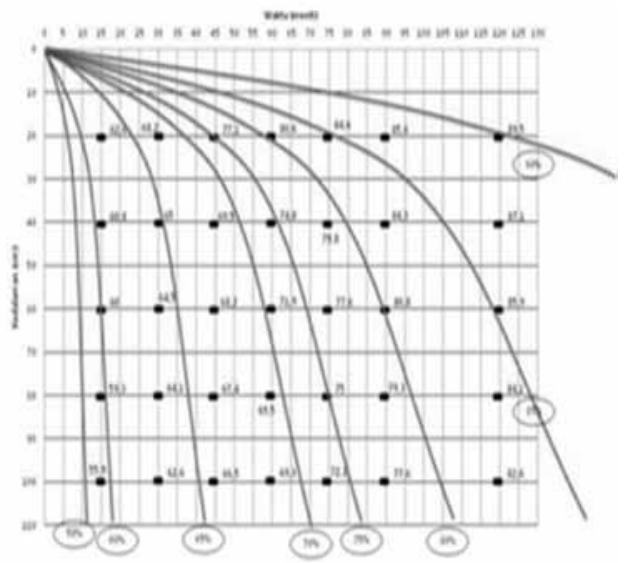

b. Alum

Gambar 6. Grafik Isoremoval Kaolin dengan Koagulan

Ekstrak Jagung dan Alum

Berdasarkan grafik isoremoval dapat dilihat penyisihan total padatan tersuspensi selama waktu pengukuran. Selain itu dapat pula ditentukan persentase penyisihan total padatan tersuspensi pada waktu tertentu seperti terlihat pada Gambar 7 dan over flowrate $\left(\mathrm{V}_{\mathrm{o}}\right)$ seperti pada Gambar 8 .

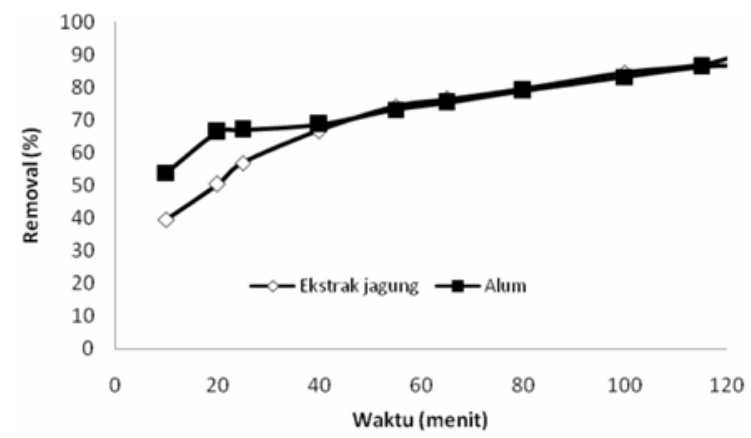

Gambar 7. Grafik Hubungan Penyisihan Padatan Tersuspensi dengan Waktu

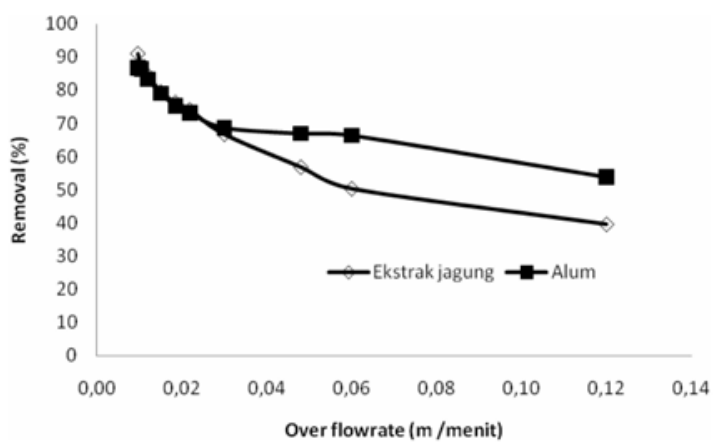

Gambar 8. Grafik Hubungan Penyisihan Padatan dengan Over Flowrate 
Berdasarkan Gambar 6, 7, dan 8 dapat dilihat bahwa setelah pengendapan berlangsung selama 40 menit akan diperoleh efisiensi penurunan padatan tersuspensi sebesar 68,73 \%. Pada kondisi tersebut didapatkan nilai over flowrate sebesar $0,03 \mathrm{~m} /$ menit. Berdasarkan gambar tersebut dapat dilihat bahwa pada nilai over flowrate kurang dari $0,03 \mathrm{~m} / \mathrm{menit}$ diperoleh persentase penyisihan padatan tersuspensi yang hampir sama antara ekstrak jagung dengan alum. Akan tetapi, pada nilai over flowrate yang lebih tinggi dari $0,03 \mathrm{~m} / \mathrm{menit}$, alum akan memberikan efisiensi penyisihan padatan yang lebih besar. Berdasarkan hasil tersebut, maka alum sangat tepat digunakan untuk proses pengendapan partikel dengan ukuran besar, sedangkan ekstrak jagung lebih sesuai untuk proses pengendapan partikel dengan ukuran yang lebih kecil.

\section{Morfologi Flok}

Sebelum dan sesudah proses koagulasi dilakukan analisis SEM untuk mengetahui morfologi koagulan jagung dan flok yang terbentuk. Selain itu dilakukan pula uji EDX untuk mengetahui komposisi dalam koagulan dan flok. Hasil uji SEM-EDX dapat dilihat pada Gambar 9.

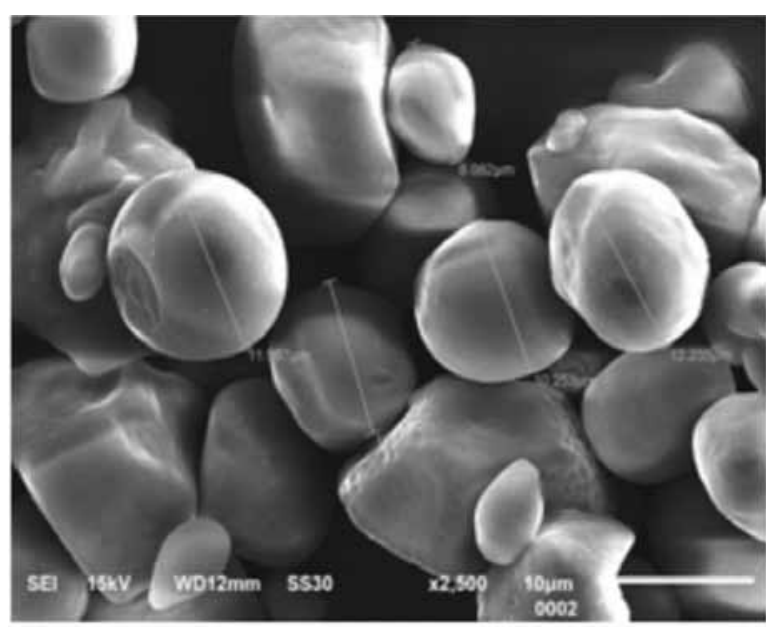

a. Tepung jagung

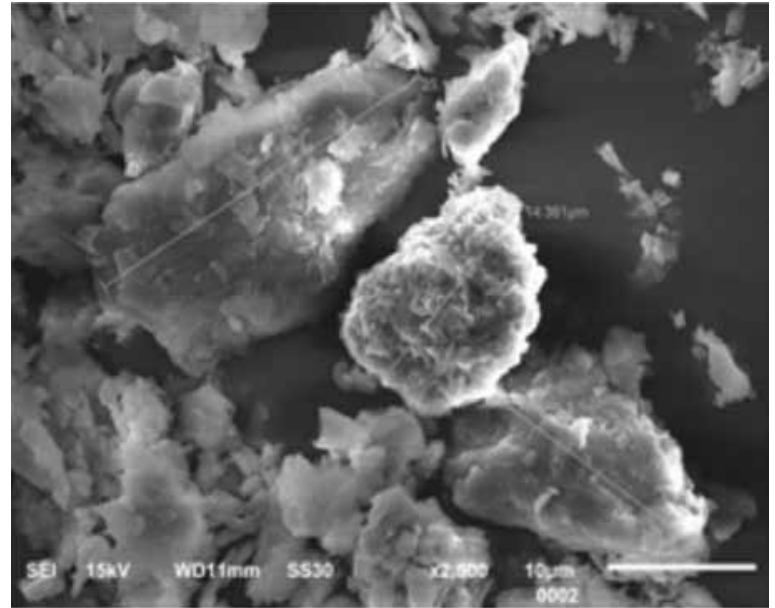

b. Flok

Gambar 9. Morfologi Tepung Jagung dan Flok Hasil Koagulasi

Sebelum proses koagulasi, bentuk morfologi tepung jagung cenderung seperti bola dengan ukuran berkisar antara 8,082 $12,255 \mu \mathrm{m}$. Bentuk ini mengalami perubahan setelah proses koagulasi. Flok yang terbentuk mempunyai tekstur yang lebih kasar, tidak beraturan, dan ukuran yang lebih besar yaitu 14,361 - 25,126 $\mu \mathrm{m}$. Perubahan ini terjadi karena partikel koloid dalam limbah, yaitu aluminium dan silika sebagai komponen utama kaolin, terjebak dalam tepung jagung, dan membentuk flok. Komposisi tepung jagung dan koloid yang terjebak dalam flok dapat dilihat pada Tabel 2.

Tabel 2. Komposisi Tepung Jagung dan Flok

\begin{tabular}{lll}
\hline Senyawa & $\begin{array}{c}\text { Tepung jagung } \\
\text { (\% berat) }\end{array}$ & \multicolumn{1}{c}{$\begin{array}{c}\text { Flok (\% } \\
\text { berat) }\end{array}$} \\
\hline $\mathrm{C}$ & 41,08 & 4,50 \\
$\mathrm{~N}$ & 19,35 & - \\
$\mathrm{O}$ & 39,56 & 49,46 \\
$\mathrm{Al}$ & - & 14,48 \\
$\mathrm{Si}$ & - & 31,56 \\
\hline
\end{tabular}

Berdasarkan Tabel 2 dapat dilihat bahwa komposisi utama dalam tepung jagung adalah karbon, nitrogen, dan oksigen. Komposisi utama dalam flok didominasi oleh silika dan aluminium dari kaolin. Hal ini menjelaskan bahwa silika dan aluminium 
dalam koloid telah terjebak dalam koagulan sehingga membentuk flok.

\section{SIMPULAN}

Jagung dapat digunakan sebagai koagulan alami. Hal ini didasarkan pada sifatnya yang polielektrolit. Gugus yang berperan pada proses koagulasi adalah gugus karboksil, hidroksil, dan amida. Larutan elektrolit ini bersifat amfoter

Hasil koagulasi memberikan efisiensi penurunan kekeruhan yang cukup signifikan. Jagung ionik memberikan hasil penurunan kekeruhan yang sedikit lebih baik jika dibandingkan dengan ekstrak jagung. Proses koagulasi berjalan dengan efisien pada $\mathrm{pH}$ 5 karena pada titik tersebut diperoleh titik isoelektrik. Kekeruhan awal yang tinggi akan memberikan efisiensi penurunan kekeruhan yang lebih besar daripada kekeruhan awal yang rendah. Mekanisme koagulasi flokulasi yang terjadi adalah netralisasi dan pembentukan interparticulate bridging. Kecepatan pengendapan kaolin dengan menggunakan alum dan ekstrak jagung akan sama pada over flowrate sebesar $0,03 \mathrm{~m} /$ menit atau kurang. Pada over flowrate lebih dari 0,03 $\mathrm{m} / \mathrm{menit}$, kecepatan pengendapan dengan alum akan memberikan hasil yang lebih baik daripada ekstrak jagung.

\section{DAFTAR PUSTAKA}

Antov,M.G., Sciban, M.G., and Petrovic, N.J, 2010, Proteins from Common Bean (Phaseolus vulgaris) Seed as A Natural Coagulant for Potential Application in Water Turbidity Removal, Bioresource Technology, Vol. 101, pp, 2167-2172.

Bhuptawat, H., Folkard, G.K, and Chaudari, S, 2007, Innovative Physico-Chemical Treatment of Wastewater Treatment Incorporating Moringa oleifera Seed Coagulant, Journal of Hazardous Materials, Vol. 142, pp, 477 - 482.
Fatehah, 2007, Semiconductor Wastewater Treatment with Natural Starch as Coagulant Using Responce Surface Methodology, Univesiti Teknologi Malaysia.

Heredia, J.B., Martin, J.S., and Acedo, M.A.D., 2011, Otimization of the Synthesis of New Coagulant from Tannin Extract, Journal of Hazardous Material, Vol. 186, pp, 1704 - 1712.

Jeon, J.K., Kim, E.J., Kim, Y.M., Murugesan, K., Kim, J.H., and Chang, Y.S, 2009, Use of Grape Seed and its Natural Polyphenol Extracts as a Natural Organic Coagulant for Removal Cationic Dyes, Chemosphere, Vol. 77, pp, 1090 - 1098.

Katayon, S., Noor, M.J.M.M., Tat, W.K., Halim, G.A., Thamer, A.M., and Badronisa, Y, 2007, Effect of Natural Coagulant Application on Microfiltration Performance in Treatment on Secondary Oxidation Pond Effluent, Desalination, Vol. 204, pp, $204-212$.

Kawamura, S, 1991, Integrated Design and Operation of Water Treatment Facilities, Wiley, New York.

Moreno, J.M.G, 2009, Application of Natural Coagulant Derived from Opuntia sp in Water Treatment, Alicante University.

Ozacar, M., and Sengil, I.A, 2003, Evaluation of Tannin as a Coagulant Aid for Coagulation of Colloidal Particles, Colloid and Surfaces A, Physicochem, Eng. Aspects, Vol. 229. Pp 85 - 96.

Patel,H. and Vashi, R.T, 2011, Removal of Congo Red Dye from its Aqueous Solution using natural Coagulants, Journal of Saudi Chemical Society.

Reynolds, T.D., 1982, Unit Operation and Processes in Environmental Engineering, Wadsworth, Montery California. 
JURNAL 『ERKNOSAINS | VOL 2, NO. 2, JUNI 2013 ; 93-102

Srawaili, N, 2008, Efektivitas Biji Kelor (Moringa oleifera) dalam Menurunkan Kekeruhan, Kadar Ion Besi, dan Mangan dalam Air, Master Thesis Program Studi Kimia Institut Teknologi Bandung.

Yin,C.Y, 2010, Emerging Usage of PlantBased Coagulants for Water and
Wastewater Treatment, Process Biochemistry, Vol. 45, Pp, 1437 - 1444.

Zubachtirodin, Pabbage, M.S, dan Subandi, 2010, Wilayah Produksi dan Potensi Pengembangan Jagung, Balai Penelitian Tanaman Serealia, Maros. 